Dapat diakses pada: http://jkb.ub.ac.id/index.php/jkb/article/view/1874

Jurnal Kedokteran Brawijaya Vol. 29, No. 04, Agustus 2017, pp. 287-292

Online Published First: 31 Agustus 2017

Article History: Received 23 November 2016, Accepted 10 April 2017

$\underline{\text { Artikel Penelitian }}$

\title{
Pengaruh Pemberian Ekstrak Propolis terhadap Ekspresi TLR4 dan Apoptosis pada Jaringan Otak Tikus Model Traumatic Brain Injury (TBI)
}

\section{The Effect of Propolis Extract Administrations on TLR4 Expression and Apoptosis in Rats' Brain Model of Traumatic Brain Injury}

\author{
Bowo Hery Prasetyo ${ }^{1}$, Kusworini Handono², Mochamad Dalhar ${ }^{1}$ \\ ${ }^{1}$ Laboratorium Ilmu Penyakit Saraf Rumah Sakit Umum Daerah Dr. Saiful Anwar Malang \\ ${ }^{2}$ Laboratorium Patologi Klinik Rumah Sakit Umum Daerah Dr. Saiful Anwar Malang
}

\begin{abstract}
ABSTRAK
Traumatic brain injury (TBI) merupakan cedera kepala yang sering terjadi pada populasi di seluruh dunia. Selama cedera kepala terjadi reaksi kaskade inflamasi yang dihubungkan dengan aktivasi TLR4. Propolis adalah produk lebah dengan kandungan flavonoid tinggi yang mempunyai efek antioksidan, anti inflamasi, proteksi DNA, neuroprotektan, dan immunomodulator. Kandungan propolis berupa Caffeic Acid Phenethyl Ester (CAPE) dapat menekan reperfusi iskemia, mencegah aktifasi TLR4, menghambat produksi sitokin proinflamasi dan menghambat produksi ROS pada level transkripsi melalui supresi aktivasi NFkB sehingga akan menghambat apoptosis. Penelitian ini bertujuan untuk menguji pengaruh pemberian ekstrak propolis dalam berbagai dosis pada ekspresi TLR4 dan apoptosis di jaringan otak tikus Rattus norvegicus model trauma kapitis. Metode yang digunakan dalam penelitian ini adalah imunohistokimia dan DNA terfragmentasi (TUNEL). Sampel dibagi menjadi 5 kelompok, yaitu: kelompok model trauma dan perlakuan propolis masing-masing dosis $50 \mathrm{mg}, 100 \mathrm{mg}$, dan $200 \mathrm{mg}$, kontrol positif dan kontrol negatif. Pada akhir penelitian, tikus dikorbankan dan dibuat preparat otak untuk menilai ekspresi TLR4 dan apoptosis. Berdasarkan hasil analisis statistik, didapatkan hubungan yang signifikan antara ekspresi TLR4 dan apoptosis sel otak tikus model traumatik dengan berbagai dosis propolis ( $p=0,000, r=-0,903, p=0,000, r=-0,907$, Korelasi Pearson). Penelitian ini membuktikan bahwa propolis berpengaruh dalam penurunan ekspresi TLR4 dan apoptosis di sel otak tikus model trauma kapitis.
\end{abstract}

Kata Kunci: Apoptosis, Propolis, TLR4, Traumatic brain injury (TBI)

\section{ABSTRACT}

Traumatic brain injury (TBI) is a common head injury in populations around the world. During a head injury, a cascade of inflammatory reactions is associated with TLR4 activation. Propolis is a product of bees with high flavonoid content that has antioxidant, anti-inflammatory effect, DNA protection, neuroprotectant, and immunomodulator. Propolis contains caffeic acid phenethyl ester (CAPE) that can suppress ischemic reperfusion, prevent TLR4 activation, and inhibit proinflammatory cytokine release and ROS production in transcription level through suppression of NFkb activation which will prevent apoptosis. This study aimed to examine the effect of propolis extract administration in various doses on TLR4 expression and apoptosis in rat brain tissue Rattus norvegicus model of capitis trauma. The method used in this research is immunohistochemistry and fragmented DNA (TUNEL) assay. The rats were divided into 5 groups, namely positive control group, negative control group, and trauma groups treated with $50 \mathrm{mg}, 100 \mathrm{mg}$, and $200 \mathrm{mg}$ of propolis extract. At the end of the study, all rats were euthanized and brain preparations were made to assess the expression of TLR4 and the rate of apoptosis. The results showed a significant correlation between the expression of TLR4 and rate of apoptosis in traumatic models of rat brain cells with different doses of propolis ( $p=0,000, r=-0,903, p=0,000, r=-0,907$, Pearson Correlation). This study proved that propolis is significant in decreasing expression of TLR4 and apoptosis in traumatic models of rat brain cells.

Keywords: Apoptosis, Propolis, TLR4, Traumatic brain injury (TBI)

Korespondensi: Bowo Hery Prasetyo. Laboratorium Ilmu Penyakit Saraf Rumah Sakit Umum Daerah Dr. Saiful Anwar Malang, Jl. Jaksa Agung Suprapto No. 2 Malang Tel. (0341) 366242 Email: bowo_ckm@yahoo.com

DOI: http://dx.doi.org/10.21776/ub.jkb.2017.029.04.1 


\section{PENDAHULUAN}

Traumatic brain injury (TBI) merupakan cedera kepala yang sering terjadi di seluruh dunia terutama pada dewasa muda, yaitu sekitar $2 \%$ dari seluruh populasi setiap tahun. Di Amerika Serikat, terjadi lebih dari 1,7 juta kasus cedera kepala dan mengakibatkan $50 \%$ kematian dari seluruh kejadian trauma serta dibutuhkan biaya yang tinggi yaitu mencapai 10 milyar dolar untuk penatalaksanaan cedera kepala setiap tahun (1,2). Di Indonesia, jumlah kasus cenderung meningkat. Data cedera kepala di Rumah Sakit Dr. Wahidin Sudirohusodo Makasar tahun 2005 berjumlah 861 kasus, tahun 2006 berjumlah 817 kasus dan tahun 2007 berjumlah 1078 kasus. Pada penelitian lain, dalam kurun waktu Nopember 2011-April 2012 ditemukan 524 penderita cedera kepala (3).

Kondisi TBI menyebabkan kematian sel dan disfungsi neurologi melalui gangguan fisik terhadap jaringan secara langsung (cedera primer) dan juga melalui mekanisme patofisiologi molekuler dan seluler reversible dan lambat (cedera sekunder). Selama cedera kepala terjadi reaksi kaskade inflamasi. Respon inflamasi dihubungkan dengan aktivasi imunitas alamiah, khususnya Toll-like receptors (TLRs). Reseptor ini berespon terhadap patogen dan cedera jaringan, dan berperan dalam neurodegenerasi dan cedera neuron. Ekspresi TLR4 dari mikroglia memediasi neuroinflamasi melalui jalur nuclear factor kappa B (NF-kB) sebagai respon terhadap hipoksia (4). Cedera otak yang disebabkan oleh iskemia serebral adalah perjalanan patofisiologi yang kompleks. TLR2 dan TLR4 berperan penting dalam modulasi respon inflamasi. Sinyal TLRs mengaktivasi faktor transkripsi dan menghasilkan sitokin dan kemokin melalui jalur intraseluler (5). TLR4 dapat meningkatkan produksi mediator inflamasi utama seperti TNF- $\alpha$, IL-1 $\beta$, iNOS, ROS dan NO, yang berimplikasi pada kematian oligodendrosit dan neuron juga berperan pada cedera otak hipoksia neonatus (6).

Manifestasi cedera otak sekunder antara lain peningkatan tekanan intrakranial, kerusakan otak iskemik, hipoksia serebral dan hiperkarbia, serta terganggunya autoregulasi serebral. Kaskade cedera otak sekunder tersebut pada akhirnya akan memicu apoptosis sel-sel neuron. Apoptosis, suatu bentuk kematian sel terprogram, diatur ketat oleh ekspresi atau aktivasi beberapa gen dan protein. Mekanisme apoptosis terjadi melalui dua jalur, yaitu caspase-dependent dan caspase-independent. Caspase-dependent pathway dapat melalui jalur intrinsik yang dipicu oleh kegagalan metabolik mitokondria atau jalur ekstrinsik yang dipicu oleh reseptor tumor necrosis factor (TNF) $(7,8)$. Caspase-independent pathway dipicu oleh protein mitokondria seperti apoptosis inducing factor (AIF) yang keluar dari membran mitokondria akibat depolarisasi membran luar mitokondria $(7,8)$.

Sampai saat ini terapi TBI masih difokuskan pada pengendalian hipertensi intrakranial. Terobosan dalam terapi TBI terhambat oleh kurangnya pemahaman tentang mekanisme kunci yang bekerja pada otak yang cedera (9). Hambatan TLR4 secara efektif dapat menghambat pelepasan mediator inflamasi pada tikus neonatus hipoksia. Inhibisi ekspresi TLR4 pada mikroglia secara efektif menekan ekspresi berlebihan faktor inflamasi yang disebabkan stres hipoksia. Inhibisi TLR4 secara in vivo menurunkan ekspresi TNF- $\alpha$, IL- $\beta$, dan iNOS pada mikroglia pasca hipoksia (6).
Propolis adalah produk lebah dengan kandungan flavonoid yang tinggi (10). Beberapa penelitian menunjukkan bahwa propolis memiliki aktifitas antioksidan dan antiinflamasi yang kuat. Propolis mampu menurunkan reaksi inflamasi melalui hambatan terhadap aktifitas TNF dan NF-kB. Propolis terbukti mampu menetralisir berbagai radikal bebas dalam tubuh seperti reactive oxygen species (ROS) dan reactive nitrogen species (RNS). Beberapa penelitian menunjukkan bahwa caffeic acid phenethyl ester (CAPE) adalah salah satu komponen propolis yang bernilai untuk neuroprotektif. Oxygen-derived free radical mempunyai implikasi terhadap patogenesis cedera otak setelah iskemia-reperfusi (11-13). CAPE dapat melindungi medula spinalis dari cedera iskemia reperfusi (14). CAPE dapat mencegah aktivasi TLR4 melalui gangguan interaksi ligand dengan kompleks reseptor (TLR4/MD2) (15).

Kajian menunjukkan bahwa sebelumnya propolis tersebut memiliki potensi sebagai terapi ajuvan dalam menurunkan ekspresi TLR4 dan apoptosis pada cedera otak traumatik. Pemberian ekstrak propolis diharapkan dapat membantu mencegah komplikasi cedera sekunder yang mungkin terjadi. Berdasarkan latar belakang di atas, dilakukan penelitian pengaruh pemberian ekstrak propolis pada tikus model cedera otak traumatik.

\section{METODE}

\section{Desain Penelitian}

Penelitian ini menggunakan desain eksperimental sebenarnya (true experimental design) secara in vivo dengan randomized post test only controlled group design pada hewan model tikus wistar (Rattus novergicus galur wistar). Kriteria inklusi yang digunakan adalah tikus putih Rattus novergicus jantan, usia 6-8 minggu, berat 150-200 gram, sehat dan aktif, sedangkan kriteria drop out adalah tikus yang sakit dan mati pada saat penelitian berlangsung.

Dalam penelitian ini, terdapat tiga kelompok perlakuan dan dua kelompok kontrol, yaitu: kelompok A (kontrol positif, model cedera otak trumatik tanpa diberi ekstrak propolis, kelompok B (kontrol negatif, tanpa cedera otak traumatik dan tanpa diberi ekstrak propolis), kelompok C (model cedera otak traumatik yang diberi ekstrak propolis $50 \mathrm{mg} / \mathrm{kgbb}$ ), kelompok $\mathrm{D}$ (model cedera otak traumatik yang diberi ekstrak propolis $100 \mathrm{mg} / \mathrm{kgbb}$ ), dan kelompok $\mathrm{E}$ (model cedera otak traumatik yang diberi ekstrak propolis $200 \mathrm{mg} / \mathrm{kgbb}$ ).

Semua protokol yang berkaitan dengan hewan coba telah mendapat persetujuan Komite Etik Penelitian Kesehatan Fakultas Kedokteran Universitas Brawijaya (387A/EC/KEPK-PPDS/07/2015).

\section{Model Cedera Otak Traumatik}

Tikus dianestesi, kemudian diletakkan di bawah alat penjatuh beban dengan diikat keempat kakinya sehingga terfiksasi dengan alas/dasar yang keras. Silinder besi seberat 45 gram (diameter $4 \mathrm{~mm}$ ) dijatuhkan dengan sudut $90^{\circ}$ dari ketinggian $100 \mathrm{~cm}$ sebanyak 1 kali. Benturan dengan energi 0,5 joule $(16,17)$.

\section{Ekstraksi Propolis}

Teknik ekstraksi propolis dilakukan seperti yang telah dilaporkan sebelumnya oleh Damayanti et al, dan Husna et al, $(16,17)$. Terapi propolis diberikan secara oral setiap 
hari selama 7 hari dengan dosis 50, 100 dan 200mg/kgBB. Kandungan zat aktif pada ekstraksi propolis ini tidak diidentifikasi dan tidak ditentukan kadarnya.

\section{Isolasi Jaringan Otak}

Pembedahan tikus dilakukan seperti yang telah dilaporkan sebelumnya oleh Chandra et al, (18). Pengirisan jaringan otak dan pembuatan slide dengan paraffin block dilakukan di Laboratorium Patologi Anatomi RSUD Dr. Soetomo.

\section{Pemeriksaan TLR4 dengan Teknik Imunohistokimia}

Teknik imunohistokimia dilakukan seperti yang telah dilaporkan sebelumnya oleh Chandra et al, dan Husna et al, $(17,18)$. Inkubasi menggunakan rabbit polyclonal anti TLR4 (Santa Cruz) dan antibodi sekunder berlabel biotin conjugated. Pengamatan dilakukan pada mikroskop cahaya dengan pembesaran 400x dan dilakukan penghitungan sel yang positif pada 10 lapang pandang dan dicari reratanya. Sel positif menunjukkan sitoplasma yang terwarnai coklat. Pemeriksaan dilakukan oleh peneliti dan peneliti lain (2 orang) sebanyak 2 kali pemeriksaan. Hasil pengamatan dikonfirmasi oleh ahli patologi anatomi Rumah Sakit dr Syaiful Anwar, Malang.

Pemeriksaan Apoptosis dengan Teknik DNA Terfragmentasi (Tunel)

Teknik DNA terfragmentasi (Tunel) dilakukan seperti yang telah dilaporkan sebelumnya oleh Chandra et al., Husna et al, dan Annis et al, $(17,19)$. Slide diamati dibawah mikroskop cahaya dengan pembesaran 400x dan dilakukan penghitungan sel yang positif pada 10 lapang pandang dan dicari reratanya. Sel apoptosis ditunjukkan dengan warna coklat pada inti sel. Pemeriksaan dilakukan oleh peneliti dan peneliti lain ( 2 orang) sebanyak 2 kali pemeriksaan. Hasil Pengamatan dikonfirmasi oleh ahli patologi anatomi Rumah Sakit dr Syaiful Anwar, Malang.

\section{Analisis Statistik}

Data dianalisis secara statistik dengan menggunakan uji one-way ANOVA, dilanjutkan dengan Post Hoc Test (Tukey HSD), uji korelasi Pearson, dan regresi linier. Hasil uji statistik dianggap bermakna secara statistik bila $p<0,05$.

\section{HASIL}

Pengaruh Pemberian Ekstrak Propolis terhadap Ekspresi TLR4 pada Tikus Wistar Model TBI

Pemeriksaan ekpresi TLR4 dilakukan melalui pemeriksaan imunohistokimia pada sampel otak tikus wistar menggunakan mikroskop dengan pembesaran 400x. Sel yang mengekpresikan TLR4 akan menunjukkan sitoplasma berwarna coklat. Sampel pemeriksaan histologi pada penelitian ini ditunjukkan pada Gambar 1. Walaupun hanya perwakilan dari 200 lapang pandang yang diperiksa, dari gambar tersebut dapat dilihat bahwa pada kontrol positif terlihat paling banyak menunjukkan sel yang positif mengekpresikan TLR4. Sebaliknya kontrol negatif menunjukkan tidak ada sel yang positif mengekspresikan TLR4. Selain itu, pada gambar 1 menunjukkan adanya penurunan jumlah sel positif yang mengekspresikan TLR4 seiring dengan peningkatan dosis propolis yang diberikan.
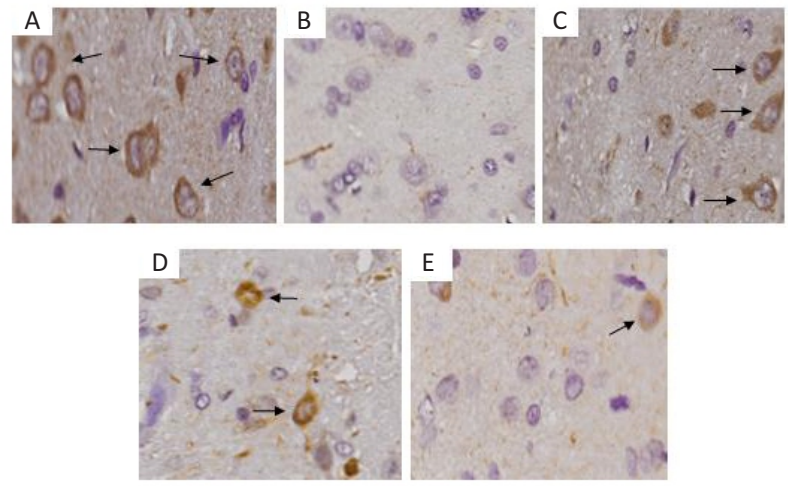

\section{Gambar 1. Hasil pengecatan imunohistokimia kelompok} kontrol dan kelompok perlakuan.

Keterangan : A. Kontrol (+). B. Kontrol (-). C. Ekstrak propolis dosis 1 (50 $\mathrm{mg} / \mathrm{kgbb})$. D. Ekstrak propolis dosis 2 (100 mg/kgbb). E. Ekstrak propolis dosis $3(200 \mathrm{mg} / \mathrm{kgbb})$. Tanda panah hitam menunjukkan sel yang mengekspresikan TLR4. Sel yang mengekspresikan TLR4 sitoplasma tercat coklat. (Ketidakseragaman, akibat pengambilan gambar secara acak)

Pengukuran dilakukan dengan cara menghitung rerata sel yang mengekspresikan TLR4 melalui pengamatan 10 lapang pandang dari setiap slide. Hasil pengamatan dibawah mikroskop, ekspresi TLR4 ditunjukkan pada gambar 2.

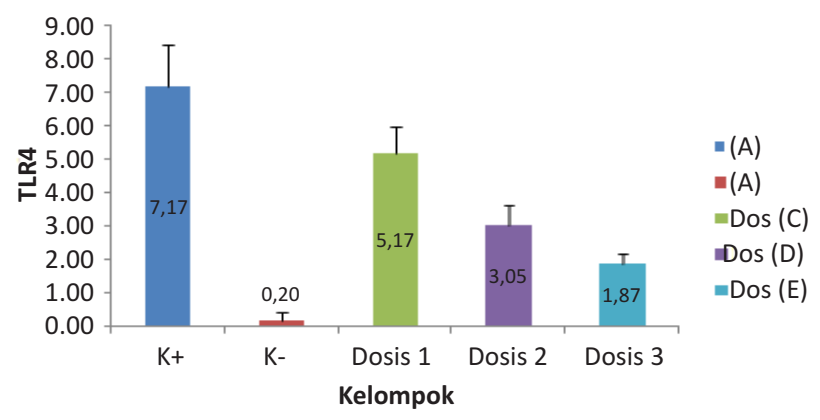

Gambar 2. Grafik histogram rata-rata ekspresi TLR4 kelompok perlakuan dan kelompok kontrol.

Hasil menunjukkan pemberian perlakuan trauma kepala menunjukkan gambaran ekspresi TLR4 yang jauh lebih tinggi dibandingkan kontrol normal. Dari histogram juga ditunjukkan bahwa dengan semakin tinggi dosis ekstrak propolis, penurunan ekspresi TLR4 juga semakin besar. Hal ini dibuktikan dengan uji oneway ANOVA yang dilanjutkan dengan uji Tukey bahwa ada perbedaan yang signifikan secara statistik antar kelompok dengan perbedaan dosis. Hubungan dosis dan respon ekspresi TLR4 ini dibuktikan dari uji korelasi Pearson $(r=-0,903, p<0,001)$ yang menunjukkan hubungan negatif yang kuat dan signifikan secara statistik. Peningkatan dosis ekstrak propolis terbukti menurunkan ekspresi TLR4.

Pengaruh Pemberian Ekstrak Propolis terhadap Apoptosis pada Tikus Wistar Model TBI

Slide diamati dibawah mikroskop cahaya dengan pembesaran 400x dan dilakukan penghitungan sel yang positif pada 10 lapang pandang dan dicari reratanya. Sel apoptosis ditunjukkan dengan warna coklat pada inti sel. 
Gambar 3 dan 4 menunjukkan penurunan jumlah sel apoptosis seiring dengan peningkatan dosis ekstrak propolis yang diberikan pada tikus model cedera otak traumatik.
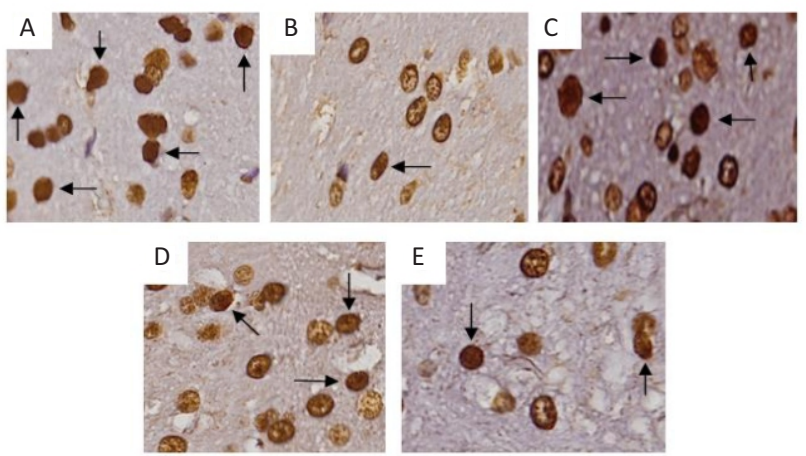

Gambar 3. Ekspresi apoptosis dengan imunohistokimia tunel assay pada kelompok kontrol dan kelompok perlakuan

Keterangan: A. Kontrol (+). B. Kontrol (-). C. Ekstrak propolis dosis 1 $(50 \mathrm{mg} / \mathrm{kgbb})$. D. Ekstrak propolis dosis $2(100 \mathrm{mg} / \mathrm{kgbb})$. E. Ekstrak propolis dosis $3(200 \mathrm{mg} / \mathrm{kgbb})$. Tanda panah hitam menunjukkan sel apoptosis. Sel apoptosis ditunjukkan dengan warna coklat pada inti sel. (Ketidakseragaman, akibat pengambilan gambar secara acak)

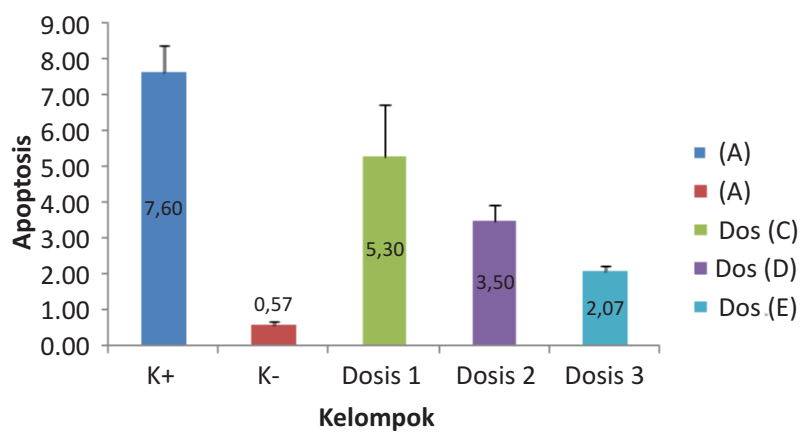

Gambar 4. Grafik histogram rata-rata nilai apoptosis kelompok perlakuan dan kelompok kontrol

Pemberian perlakuan trauma kepala menunjukkan rerata apoptosis yang jauh lebih tinggi dibandingkan kontrol normal. Gambaran histogram mengindikasikan bahwa dengan semakin tinggi dosis ekstrak propolis, penurunan rerata apoptosis juga semakin besar. Hal ini diperkuat dengan uji oneway ANOVA yang dilanjutkan dengan uji Tukey bahwa ada perbedaan yang signifikan secara statistik rerata skor apoptosis antar kelompok dengan perbedaan dosis. Hubungan dosis apoptosis ini dibuktikan dari uji korelasi Pearson ( $r=-0,907, p<0,001$ ) yang menunjukkan hubungan negatif yang kuat dan signifikan secara statistik. Peningkatan dosis ekstrak propolis terbukti menurunkan apoptosis secara bermakna.

\section{Hubungan antara Ekspresi TLR4 dan Apoptosis}

Uji korelasi Pearson menunjukkan hubungan positif kuat dan signifikan $(r=0,904 ; p<0,001)$ antara ekspresi TLR4 dengan apoptosis. Peningkatan ekspresi TLR4 meningkatkan rerata apoptosis.

\section{DISKUSI}

Pengaruh Pemberian Ekstrak Propolis terhadap Ekspresi TLR4

Hasil penelitian ini menunjukkan bahwa pada semua kelompok perlakuan yang mendapat ekstrak propolis terjadi penurunan ekspresi TLR4 yang signifikan dibandingkan kelompok tikus dengan cedera otak traumatik tanpa pemberian ekstrak propolis (kontrol positif). Penurunan ekspresi TLR4 setelah pemberian perlakuan dosis ekstrak propolis dapat dijelaskan sebagai berikut. Propolis adalah produk lebah, yang mengandung flavonoid tinggi yang mempunyai efek antioksidan dan anti inflamasi yang kuat. Propolis mampu menurunkan reaksi inflamasi melalui hambatan terhadap aktifitas TNF dan NFkB (13). Respon inflamasi biasanya dihubungkan dengan aktifasi imunitas alamiah, khususnya Toll-like receptors (TLRs), molekul kunci dalam regulasi respon imun selama infeksi dan kerusakan sistem saraf pusat (SSP) (4). Cedera otak yang disebabkan oleh iskemia serebral adalah perjalanan patofisiologi yang kompleks, dengan TLR2 dan TLR4 berperan penting dalam modulasi respon inflamasi. Signal TLRs mengaktifasi faktor transkripsi dan menghasilkan sitokin dan kemokin melalui jalur intraseluler (5).

Propolis mempunyai komponen neuroprotektif yang terdapat pada CAPE dan mampu menekan reperfusi iskemia akibat cedera otak dan melindungi medula spinalis dari cedera iskemia reperfusi (12-14). Menurut Tolba et al, CAPE dapat mencegah aktifasi TLR4 melalui gangguan interaksi ligand dengan kompleks reseptor (TLR4/MD2) (15). Reseptor ini berespon terhadap patogen dan cedera jaringan host, dan juga berperan dalam neurodegenerasi dan cedera neuron. Ekspresi TLR4 dari mikroglia memediasi neuroinflamasi melalui nuclear factor kappa $B$ (NF-kB) signaling pathway sebagai respon terhadap hipoksia (4). Menurut Yao et al, hipoksia menginduksi aktivasi mikroglia yang menyebabkan kerusakan perkembangan otak. Penelitian tentang ekspresi TLR4 dan perannya dalam neuroinflamasi pada tikus neonatus cedera hipoksia menyimpulkan bahwa ekspresi TLR4 pada mikroglia neonatus dalam korpus kalosum dan serebelum meningkat secara nyata pasca hipoksia. Penurunan siRNA dari TLR4 mengurangi peningkatan TNF- $\alpha$, IL-1 $\beta$, iNOS, ROS dan NO pada sel BV-2. Ekspresi TLR4 dari mikroglia memediasi neuroinflamasi melalui NF-k $\beta$ signaling pathway sebagai respon terhadap hipoksia. Penghambatan ekspresi TLR4 pada mikroglia efektif menekan ekspresi berlebihan faktor inflamasi yang disebabkan oleh hipoksia (6).

Pada sel otak tikus yang mengalami cedera traumatik, dengan tidak adanya TLR4 maka sel otak tikus akan terhindar dari edema, infark, kematian sel, dan defisit neurobehaviour. Hal ini menunjukkan bahwa respon imun terjadi segera setelah cedera otak dan berguna dalam pengembangan terapi baru untuk menghambat signal TLR4 (4). Pada penelitian Yao et al, pengaruh protektif diamati pada mikroglia serebri dan serebelum menunjukkan bahwa TLR4 dapat memediasi kerusakan di neuron, oligodendrosit dan purkinye. Penurunan nyata dalam apoptosis neuron, oligodendrosit dan purkinye ditemukan setelah menghambat TLR4 pada tikus hipoksia, meskipun bukti langsung yang berkontribusi terhadap penghambatan aktivasi mikroglia masih perlu diteliti lebih lanjut. Penghambatan aktivasi mikroglia melalui TLR4 pada cedera hipoksia neonatus dapat bersifat sebagai 
neuroprotektif (6).

Penurunan ekspresi TLR4 pada penelitian ini kemungkinan disebabkan oleh karena adanya komponen yang terkandung dalam ekstrak propolis yaitu flavonoid dan CAPE yang dapat menghambat ekspresi TLR4. Disamping itu, berdasarkan hasil penelitian juga dapat dilihat bahwa semakin tinggi dosis ekstrak propolis yang diberikan akan semakin menurunkan ekspresi TLR4. Besarnya dosis ekstrak propolis berbanding terbalik dengan ekspresi TLR4, yang menunjukkan bahwa kandungan flavonoid dan CAPE pada propolis mempunyai peranan penting dalam penurunan ekspresi TLR4.

\section{Pengaruh Pemberian Ekstrak Propolis terhadap Apoptosis}

Pada penelitian ini didapatkan hasil penurunan jumlah sel apoptosis setelah diberikan ekstrak propolis. Semakin meningkat dosis ekstrak propolis, semakin menurunkan nilai apoptosis. Hasil ini sesuai dengan hasil penelitian yang telah dilaporkan sebelumnya oleh Chandra et al, Husna et al, dan Annis et al. (17-19). Penurunan sel apoptosis setelah pemberian propolis dapat dijelaskan seperti berikut. Propolis adalah produk lebah, dimana di dalamnya terkandung flavonoid tinggi yang mempunyai efek antioksidan dan antiinflamasi kuat (20-22). Menurut penelitan Swamy et al, propolis mampu menurunkan reaksi inflamasi melalui hambatan terhadap aktifitas sitokin proinflamasi dan inflamasi seperti TNF- $\alpha$, IL 1, IL 8 (23). Propolis mampu menurunkan reaksi inflamasi melalui hambatan terhadap aktifitas TNF dan NF-kB sehingga diharapkan dapat mencegah komplikasi cedera sekunder yang mungkin terjadi (24).

Penelitian Li et al. menunjukkan flavonoid mempunyai efek neuroprotektan pada tikus model focal cerebral ischemia, menurunkan Bax, meningkatkan $\mathrm{Bcl}-2$ dan menurunkan caspase 3 (11). Penelitian Ozkara et al. pada tikus dengan trauma medula spinalis yang diberikan ekstrak propolis dosis $100 \mathrm{mg} / \mathrm{kgbb}$ dan $200 \mathrm{mg} / \mathrm{kgbb}$ pada 30 menit dan 4 jam setelah trauma menunjukkan bahwa ekstrak propolis dapat menurunkan apoptosis sel otak tikus melalui penurunan caspase 3 sebagai penanda apoptosis sel (14). Beberapa penelitian lain telah menunjukkan bahwa flavonoid mampu menurunkan ekspresi iNOS. Mekanisme molekuler flavonoid dalam menurunkan ekspresi iNOS belum diketahui secara pasti, diduga terjadi melalui hambatan aktivasi NF- $\kappa$ B dan signal transducer and activator of transcription 1 (STAT-1) yang merupakan faktor transkripsi penting untukiNOS (25).

Selain flavonoid, bahan aktif propolis yang diketahui banyak manfaatnya adalah CAPE. Beberapa penelitian telah melaporkan bahwa CAPE dalam ekstrak propolis mempunyai potensi yang besar dalam modulasi kaskade arachidonic acid. Menurut Juman et al., CAPE

\section{DAFTAR PUSTAKA}

1. Spiotta A, Stiefel MF, Gracias VH, et al. Brain Tissue Oxygen-directed Management and Outcome in Patients with Traumatic Brain Injury. Journal of Neurosurgery. 2010; 113(3): 571-580.

2. Ansari S, Agius S, and Debono P. Pediatric Head injuries-A Review. Advances in Clinical Neuroscience \& Rehabilitation. 2011; 10(6): 30-35.

3. Lisnawati, Kwandou L, Akbar M, Muis A, Kaelan C, and Patellongi I. Hubungan antara Skor Cognitive Test for menunjukkan pengaruh inhibisi pada produksi sitokin proinflamasi (IL-1 $\beta$, TNF- $\alpha$, dan MCP-1) (15). Propolis mempunyai komponen neuroprotektif in vitro dan in vivo melalui pengaruh antioksidan, anti inflamasi dan imunomodulator (11). CAPE memiliki kemampuan sebagai antioksidan. Pemberian CAPE dan alpha-tocopherol dapat menekan reperfusi iskemia akibat cerebral lipid peroxidation dan cedera otak (11-13). Selain itu, terapi dengan CAPE secara signifikan menghambat produksi ROS yang diinduksi oleh penyakit autoimmune encephalomyelitis (EAE), dan ameliorated clinical symptoms pada tikus. Hasil ini menunjukkan bahwa CAPE mempunyai efek antiinflamasi melalui inhibisi pada produksi ROS pada level transkripsi melalui supresi aktivasi NFkB, dan dengan hambatan langsung pada aktifitas katalitik dari iNOS $(26,27)$. Menurut Galvao propolis juga mempunyai aktifitas anti tumor, proteksi DNA, penangkap radikal bebas, immunomodulator, sinergi dengan kemoterapi, antiinflamasi, penyembuhan luka, dan antimikrobal (28). Dengan demikian, penurunan sel apoptosis pada penelitian model tikus TBI ini diduga disebabkan oleh karena adanya kandungan flavonoid dan CAPE dari ekstrak propolis. Dengan pemberian ekstrak propolis, respon inflamasi dan mediator-mediator inflamasi yang berlebihan dapat dihambat sehingga proses apoptosis juga terhambat.

\section{Hubungan Ekspresi TLR4 dan Apoptosis}

Penelitian ini menunjukkan bahwa semakin menurun ekspresi TLR4 akan terjadi kecenderungan penurunan sel apoptosis otak tikus model cedera traumatik. Pemberian ekstrak propolis pada penelitian ini dapat menghambat respon inflamasi dan mediator-mediator inflamasi berlebihan yang diawali oleh ekspresi TLR4, sehingga proses apoptosis dapat dihambat. Hal ini sesuai dengan referensi yang ada, bahwa peningkatan TLR4 berperan penting dalam kejadian cedera kepala yang distimulasi oleh aktifasi sel mikroglia, infiltrasi sel leukosit, dan produksi sitokin dan kemokin. Jalur signaling TLR4 meliputi cedera inflamasi yang menginduksi perdarahan dalam otak, TLR4 sendiri, protein adaptor (MyD88 dan TRIF) dan faktor transkripsi seperti NF-kB (29). Ekspresi TLR4 dari mikroglia memediasi neuroinflamasi melalui NF$\mathrm{k} \beta$ signaling pathway sebagai respon terhadap hipoksia (4). CAPE dalam ekstrak propolis dapat mencegah aktifasi TLR4 melalui gangguan interaksi ligand dengan kompleks reseptor (TLR4/MD2) (15).

Berdasar hasil penelitian ini dapat disimpulkan bahwa pemberian ekstrak propolis pada tikus dengan cedera otak traumatik mampu menurunkan ekspresi TLR4 dan apoptosis pada sel otak tikus model cedera otak traumatik.
Delirium (CTD) dengan Outcome menurut Glasgow Outcome Scale (GOS) pada Penderita Cedera Kepala Tertutup Ringan-Sedang. Jurnal Sains \& Teknologi Seri Ilmu-ilmu Kesehatan. 2012; 2(2): 163-170.

4. Ahmad A, Crupi R, Campolo M, Genovese T, Esposito $\mathrm{E}$, and Cuzzocrea S. Absence of TLR4 Reduces Neurovascular Unit and Secondary Inflammatory Process after Traumatic Brain Injury in Mice. Plos ONE. 2013; 8(3): 224-230.

5. Wang Y, Ge P, and Zhu Y. Review Article: TLR2 and 
TLR4 in Brain Injury Caused by Cerebral Ischemia and Reperfusion. Mediators of Inflammation. 2013; 2013: 1-8.

6. Yao L, Kan EM, Lu J, et al. Toll-like Receptor 4 Mediates Microglial Activation and Production of Inflammatory Mediators in Neonatal Rat Brain Following Hypoxia: Role of TLR4 in Hypoxic Microglia. Journal of Neuroinflammation. 2013; 10: 1-21.

7. Hoh NZ. BCL-2 Genotypes and Outcomes after Traumatic Brain Injury. [Dissertation]. University of Pittsburgh, Pittsburgh. 2008

8. Berridge MJ. Cell Stress, Inflammatory Responses and Cell Death. Cell Signaling Biology. 2012; 11: 1-6.

9. Namas R, Ghuma A, Hermus L, et al. The Acute Inflammatory Response in Trauma/Hemorrhage and Traumatic Brain Injury: Current State and Emerging Prospects. Libyan Journal of Medicine. 2009; 4(3): 97-103.

10. Halim E, Hardinsyah, Sutandyo N, Sulaeman A, Artika M, dan Harahap Y. Kajian Bioaktif dan Zat Gizi Propolis Indonesia dan Brasil. Jurnal Gizi dan Pangan. 2012; 7(1): 1-6.

11. Li S, Wu C, Zhu L, et al. By Improving Regional Cortical Blood Flow, Attenuating Mitochondrial Dysfunction and Sequential Apoptosis Galangin Acts as a Potential Neuroprotective Agent after Acute Ischemic Stroke. Molecules. 2012; 17(11): 1340313423.

12. Sawicka D, Car H, Borawska $\mathrm{MH}$, and Niklinski J. The Anticancer Activity of Propolis. Folia Histochemica et Cytobiologica. 2012; 50(1): 25-37.

13. Newairy A and Abdou HM. Effect of Propolis Consumption on Hepatotoxicity and Brain Damage in Male Rats Exposed to Chlorpyrifos. African Journal of Biotechnology. 2013; 12(33): 5232-5243.

14. Ozkara E, Durmaz R, Kanbak G, et al. The Effect of Propolis Following Experimental Spinal Cord Injury. World Spinal Column Journal. 2014; 5(1): 6-11.

15. Tolba MF, Azab SS, Khalifa AE, Abdel-Rahman SZ, and Abdel-Naim AB. Critical Review: Caffeic Acid Phenethyl Ester, a Promising Component of Propolis with a Plethora of Biological Activities: A Review on its Anti-inflammatory, Neuroprotective, Hepatoprotective, and Cardioprotective Effects. International Union of Biochemistry and Molecular Biology Life. 2013; 65(8): 699-709.

16. Damayanti R, Fitri LE, dan Dalhar M. Pengaruh Pemberian Propolis terhadap Ekspresi INOS dan Kadar MDA pada otak tikus Model Cedera Otak Traumatik. Jurnal Kedokteran Brawijaya. 2016; 29(2): 110-116.

17. Husna U, Sujuti H, dan Dalhar M. Pengaruh Pemberian Ekstrak Propolis terhadap Ekspresi BCl 2 dan Apoptosis pada sel Otak Tikus Model Cedera Otak Traumatik. Jurnal Kedokteran Brawijaya. 2017; 29(3): 196-201.

18. Chandra A, Ali M, dan Purnomo H. Efek Ekstrak
Propolis terhadap Ekspresi TNF $\alpha$, Apoptosis dan Nekrosis Jaringan Otak Tikus Model Traumatic Brain Injury (TBI). Jurnal Kedokteran Brawijaya. 2016; 29(2): 117-124.

19. Annis F, Purnomo H, dan Balafif F. Pengaruh Ekstrak Propolis terhadap Apoptosis Melalui Ekspresi BrainDerived Neurotrophic Factor (BDNF) pada Sel Otak Tikus Model Cedera Otak Traumatik. Jurnal Kedokteran Brawijaya. 2017; 29(3): 209-215.

20. Fialkow L, Wang Y, and Downey GP. Reactive Oxygen and Nitrogen Species as Signaling Molecules Regulating Neutrophil Function. Free Radical Biology and Medicine. 2007; 42(2): 153-164.

21. Aliyazicioglu Y, Demir S, Turan I, et al. Preventive and Protective Effects of Turkish Propolis on $\mathrm{H}_{2} \mathrm{O}_{2}$ Induced DNA Damage in Foreskin Fibroblast Cell Lines. Acta Biologica Hungarica. 2011; 62(4): 388-396.

22. Daleprane JB and Abdalla DS. Emerging Roles of Propolis: Antioxidant, Cardioprotective and Antiangiogenic Factor. Evidence-Based Complementary and Alternative Medicine. 2013; 23(3): 1-8.

23. Swamy M, Norlina W, Azman W, et al. Restoration of Glutamine Activity, Nitric Oxide Levels and Amelioration of Oxidative Stress by Propolis in Kainic Acid Mediated Excitotoxicity. Africa Journal Traditional Complementary Alternative Medicine. 2014; 11(2): 458-463.

24. Kurek-Górecka A, Rzepecka-Stojko A, Górecki M, Stojko J, Sosada M, and Swierczek-Zieba G. Structure and Antioxidant Activity of Polyphenols Derived from Propolis. Molecules. 2014; 19(1): 78-101.

25. Hamalainen M, Nieminen R, Vuorela P, Heinonen M, and Moilanen E. Anti-Inflammatory Effects of Flavonoids: Genistein, Kaempferol, Quercetin, and Daidzein Inhibit STAT-1 and NF-Kb Activations, Whereas Flavone, Isorhamnetin, Naringenin, and Pelargonidin inhibit only NF-Kb Activation along with Their Inhibitory Effect on INOS Expression and NO Production in Activated Macrophages. Mediators of Inflammation. 2007; 2007: 1-10.

26. Ozdem TA, Sarmilmaz M, Kus I, et al. Cafeic Acid Phenethyl Ester (CAPE) Prevent FormaldehydeInduced Neuronal Damage in Hippocampus of Rat. Neuroanatomy. 2007; 6: 66-71.

27. Wu Z, Zhu A, Takayama F, et al. Brazilian Green Propolis Supresses the Hipoxia-Induced Neuroinflammatory response by Inhibiting NF-KB Activation in Microglia. Oxidative Medicine and Cellular Longevity. 2013; 2013: 1-10.

28. Galvao J, Abreu, T, Cruz T, et al. Biological Theraphy Using Propolis as Nutitional Supplement in Cancer Treatment. International Journal of Cancer Research. 2007; 3(1): 43-53.

29. Fang $\mathrm{H}$, Wang $\mathrm{P}$, Zhou $\mathrm{Y}$, Wang $\mathrm{YC}$, and Yang QW. Tolllike Receptor 4 Signaling in Intracerebral Hemorrhage-Induced Inflammation and Injury. Journal of Neuroinflammation. 2013; 10: 27-36. 